\title{
Vitamin D status in Crohn's disease: association with nutrition and disease activity
}

\author{
A D HARRIES, R BROWN, R V HEATLEY, L A WILLIAMS, S WOODHEAD, \\ AND J RHODES \\ From the Departments of Gastroenterology, Biochemistry and Radiology, University Hospital of Wales, \\ Cardiff
}

SUMMARY Forty patients with Crohn's disease were divided into undernourished (18) and well nourished (22) groups depending on whether their midarm circumference was below or above $90 \%$ of the ideal standard. Plasma $25-(\mathrm{OH}) \mathrm{D} 3$ and the dihydroxylated metabolites, $24,25-(\mathrm{OH})_{2} \mathrm{D} 3$ and $1,25-(\mathrm{OH})_{2} \mathrm{D} 3$ were measured in the summer. Results were related to clinical and biochemical parameters and also compared with results from patients with ulcerative colitis and healthy subjects who served as controls. Plasma 25- $(\mathrm{OH}) \mathrm{D} 3$ was reduced in the undernourished Crohn's group compared with the well nourished Crohn's group, who did not differ from the controls. Over $50 \%$ of the undernourished Crohn's group had evidence of secondary hyperparathyroidism and raised alkaline phosphatase concentrations, although concentrations of $1,25-(\mathrm{OH})_{2} \mathrm{D} 3$ were normal. The low $25-(\mathrm{OH}) \mathrm{D} 3$ concentrations related to disease activity. It is suggested that undernourished Crohn's patients who have high levels of disease activity are at risk of vitamin D deficiency, and attempts should be made to improve their vitamin $\mathrm{D}$ nutrition.

25-hydroxy cholecalciferol $(25-(\mathrm{OH}) \mathrm{D} 3)$ is the major circulating form of vitamin $\mathrm{D}$ which requires further 1-alpha hydroxylation in the kidney to produce its active metabolite, 1,25-dihydroxy cholecalciferol $\left(1,25-(\mathrm{OH})_{2} \mathrm{D} 3\right) .{ }^{1}$ The function of $1,25-$ $(\mathrm{OH})_{2} \mathrm{D} 3$ is to raise calcium and phosphate concentrations to supersaturation and maintain normal mineralisation of newly formed bone. The metabolic production of $1,25-(\mathrm{OH})_{2} \mathrm{D} 3$ is regulated in the kidney by 1 -alpha-hydroxylase and 24 hydroxylase enzymes. In hypocalcaemic conditions parathormone is secreted and stimulates production of $1,25-(\mathrm{OH})_{2} \mathrm{D} 3$. With a return of the serum calcium to normal the renal 1-alpha-hydroxylase enzyme is shut down with a corresponding increase in the synthesis of 24,25-dihydroxy cholecalciferol $(24,25$ $\left.(\mathrm{OH})_{2} \mathrm{D} 3\right)$. The role of $24,25-(\mathrm{OH})_{2} \mathrm{D} 3$ is poorly understood although there is some evidence to suggest that it is important in bone formation. ${ }^{2}$ Various other metabolites are also produced from $25-(\mathrm{OH}) \mathrm{D} 3^{13-5}$ but their clinical significance remains uncertain,

Address for correspondence: Dr J Rhodes, University Hospital of Wales, Heath Park, Cardiff.

Received for publication 20 December 1984
Reduced concentrations of plasma 25-(OH)D3 have been reported in patients with Crohn's disease, ${ }^{67}$ possibly because of malabsorption with a broken enterohepatic circulation. Sonnenberg and his associates, ${ }^{8}$ however, found normal levels of plasma $25-(\mathrm{OH}) \mathrm{D} 3$. To examine the problem further we have measured $25-(\mathrm{OH}) \mathrm{D} 3$ and its major metabolites $1,25-(\mathrm{OH})_{2} \mathrm{D} 3$ and $24,25-(\mathrm{OH})_{2} \mathrm{D} 3$ in patients with Crohn's disease in the summer and have looked particularly at the relationship to nutritional status and disease activity.

\section{Methods}

PATIENTS

CLINICAL FEATURES

Forty patients with Crohn's disease (18 men, 22 women, aged 18-68 years) were studied during the summer. They were all outpatients and the diagnosis was based on conventional criteria with positive histology available in 30 patients. Two control groups included 20 well nourished patients with ulcerative colitis (11 men, nine women, aged 18-66 years) attending the same clinic, and nine normal healthy subjects (three men, six women, aged 22-59 years, mean 38 years). All subjects were studied 
over a two month period between May and July.

Details of clinical features in patients with inflammatory bowel disease were documented. Disease activity in Crohn's disease was based on a simple clinical index ${ }^{9}$ in which a score of five or more indicated active disease. Drug therapy was noted and at the time no subjects were receiving vitamin $\mathrm{D}$ supplements or cholestyramine.

ANTHROPOMETRIC NUTRITIONAL ASSESSMENT

Standard anthropometric measurements were carried out on all subjects during the summer and winter. These included height, weight, midarm circumference (MAC) and skinfold thickness. Midarm circumference was measured at the midpoint between acromioclavicular joint and olecranon process on the left or non-dominant side. Skinfold thickness was measured with Holtain calipers at triceps, biceps, subscapular, and suprailiac regions and the sum of these four measurements expressed as a total skinfold thickness in millimetres. Midarm muscle circumference (MAMC) was derived from midarm circumference and triceps skinfold thickness (TSF): MAMC $(\mathrm{cm})=$ MAC (cm)-0.314 TSF $(\mathrm{mm}) .{ }^{10}$ With the exception of total skinfold thickness, anthropometric measurements were expressed as a percentage of ideal standards for men and women. ${ }^{10}$ Weight was expressed as a percentage of minimum desirable weight (ideal) based on Tables compiled by the Society of Actuaries. ${ }^{11}$

Patients with Crohn's disease were divided into two groups: (1) undernourished - with midarm circumference less than $90 \%$ ideal standard $(26.4 \mathrm{~cm}$ in men, $25.7 \mathrm{~cm}$ in women) and (2) well nourished with midarm circumference at or above $90 \%$ ideal standard.

\section{LABORATORY MEASUREMENTS}

Serum albumin, total calcium, inorganic phosphate, and total alkaline phosphatase activity were measured on a Technicon SMA Plus auto analyser; total serum calcium was adjusted for serum albumin. ${ }^{12}$ Aspartate transaminase and gamma glutamyl transferase were measured by Boehringer Mannheim automated analysis, and bone and liver alkaline phosphatase enzymes were separated by electrophoresis on cellulose acetate. Serum prealbumin was estimated by radial immunodiffusion on Behring-M-partigen plates. Serum orosomucoids were measured by rate reaction nephelometry using a Beckman automated immunochemistry system. Plasma parathormone (normal range less than 1.0 $\mathrm{ng} / \mathrm{ml}$ ) was measured by automated radioimmunometric assay on a Kemtek 3000 immunoassay system. ${ }^{13}$ Patients with raised parathormone had radiographs of both hands examined by a radiologist without prior knowledge of the condition. Not all patients had every investigation.

VITAMIN D 3 ASSAYS

$25-(\mathrm{OH}) \mathrm{D} 3, \quad 24,25-(\mathrm{OH})_{2} \mathrm{D} 3$ and $1,25-(\mathrm{OH})_{2} \mathrm{D} 3$ were measured by radio immunoassay using sheep antiserum (02282), which had a high affinity for $1,25-(\mathrm{OH})_{2} \mathrm{D} 3$ but also cross reacted to a small degree with the other vitamin D3 metabolites. ${ }^{14}$ Vitamin D2 metabolites were not measured in this assay.

After preliminary extraction, both dihydroxylated metabolites, $24,25-(\mathrm{OH})_{2} \mathrm{D} 3$ and $1,25-(\mathrm{OH})_{2} \mathrm{D} 3$ were purified using Sep-Pak C18 cartridges and high performance liquid chromatography; their elution positions were checked at each assay with a reference preparation. A radioimmunoassay ${ }^{15}$ was used to measure $1,25-(\mathrm{OH})_{2} \mathrm{D} 3 ; 24,25-(\mathrm{OH})_{2} \mathrm{D} 3$ was measured in the same way but with different volumes of metabolite and reagents.

Plasma 25-(OH)D3 was extracted using methyltert-butyl-ether and radio immunoassay performed without chromatography using the method above but with some modifications. This procedure overestimates plasma concentrations of $25-(\mathrm{OH}) \mathrm{D} 3$, because all vitamin $\mathrm{D}$ metabolites are measured. The concentrations, however, were taken to reflect levels of 25-(OH)D3 because this is the predominant metabolite present in plasma.

\section{INTERASSAY REPRODUCIBILITY}

This was assessed by the coefficient of variation $(\mathrm{Cv})$ and was: $25-(\mathrm{OH}) \mathrm{D} 3-\mathrm{Cv} 7 \cdot 8 \%, \mathrm{n}=10 ; 24,25-$ $(\mathrm{OH})_{2} \mathrm{D} 3-\mathrm{Cv} 15 \cdot 1 \%, \mathrm{n}=8 ; 1,25-(\mathrm{OH})_{2} \mathrm{D} 3-\mathrm{Cv}$ $13.9 \%, \mathrm{n}=8$.

STATISTICAL ANALYSIS

Student's $t$ test for unpaired data was used to test significance between groups when the distribution of data was parametric and the Mann Whitney test for non-parametric distributions. Clinical features between Crohn's groups were compared using the $\chi^{2}$ test and correlations were based on Pearson's moment-product correlation coefficient ( $r$ ) and where specified Kendall's rank correlation coefficient $(\tau)$.

\section{Results}

CLINICAL FEATURES AND NUTRITIONAL STATUS Clinical features of the two groups with Crohn's disease and those with ulcerative colitis are in Table 1. Significantly more patients in the undernourished Crohn's group had active disease and were taking prednisolone compared with the well nourished 
Table 1 Clinical data in patients with Crohn's disease and ulcerative colitis

\begin{tabular}{|c|c|c|c|c|c|c|c|c|}
\hline & $\begin{array}{l}\text { Age }(y r) \\
\text { mean } \pm 1 S D\end{array}$ & $\begin{array}{l}\text { Male: } \\
\text { Female }\end{array}$ & $\begin{array}{l}\text { Active } \\
\text { disease }\end{array}$ & Prednisolone & $\begin{array}{l}\text { Duration } \\
\text { Symptoms } \\
(y r)\end{array}$ & Disease distribution & & Surgical resection \\
\hline $\begin{array}{l}\text { Crohn's } \\
\text { MAC }<90 \% \text { ideal }\end{array}$ & $36 \pm 17$ & $10: 8$ & $\begin{array}{l}8^{*} \\
(44 \%)\end{array}$ & $\begin{array}{l}13^{*} \\
(72 \%) \\
\text { Mean daily } \\
\text { dose } 11 \mathrm{mg}\end{array}$ & 10 & $\begin{array}{l}\text { Ileocaecal } \\
\text { Ileocolon } \\
\text { Diffuse small } \\
\text { bowel } \\
\text { Colon }\end{array}$ & $\begin{array}{l}9 \\
4\end{array}$ & $\begin{array}{l}10(56 \%) \\
\text { Mean small bowel } \\
\text { length resected } 70 \mathrm{~cm} \\
\text { Recurrence } 7\end{array}$ \\
\hline $\begin{array}{l}\text { Crohn's } \\
\text { MAC }>90 \% \text { ideal }\end{array}$ & $41 \pm 14$ & $9: 13$ & $\begin{array}{l}3 \\
(14 \%)\end{array}$ & $\begin{array}{l}8 \\
(36 \%) \\
\text { Mean daily } \\
\text { dose } 8 \mathrm{mg}\end{array}$ & 13 & $\begin{array}{l}\text { Ileocaecal } \\
\text { Ileocolon } \\
\text { Diffuse small } \\
\text { bowel } \\
\text { Colon } \\
\text { Anorectal }\end{array}$ & $\begin{array}{r}10 \\
3\end{array}$ & $\begin{array}{l}13(59 \%) \\
\text { Mean small bowel } \\
\text { length resected } 50 \mathrm{~cm} \\
\text { Recurrence } 9\end{array}$ \\
\hline $\begin{array}{l}\text { Ulcerative } \\
\text { colitis }\end{array}$ & $45 \pm 17$ & $11: 9$ & 7 & 5 & 12 & $\begin{array}{l}\text { Rectal } \\
\text { Distal } \\
\text { Total }\end{array}$ & $\begin{array}{l}5 \\
9 \\
6\end{array}$ & - \\
\hline
\end{tabular}

Patients with Crohn's disease are in: (1) Undernourished group - midarm circumference $<90 \%$ ideal standard.

(2) Well nourished group - midarm circumference $>90 \%$ ideal standard.

${ }^{*} \mathrm{p}<0.05-$ significant differences between the two groups of patients with Crohn's disease.

Crohn's group. In other respects the two Crohn's groups were similar. In Crohn's disease, serum orosomucoids (mean \pm one SD) were significantly higher in the undernourished $(1.27 \pm 0.62 \mathrm{~g} / \mathrm{l}) \mathrm{com}-$ pared with the well nourished group $(0 \cdot 75 \pm 0 \cdot 2 \mathrm{~g} / \mathrm{l}$, $\mathrm{n}=15) \mathrm{p}<0.01$; the latter group did not differ from patients with ulcerative colitis $(0 \cdot 77 \pm 0 \cdot 35 \mathrm{~g} / \mathrm{l}, \mathrm{n}=17)$ or normal subjects $(0 \cdot 59 \pm 0 \cdot 19 \mathrm{~g} / \mathrm{l})$.

In Crohn's disease undernourished patients had significantly reduced nutritional parameters of weight, midarm muscle circumference and total skinfold thickness, compared with well nourished patients who were similar to the other two groups (Table 2). The low anthropometric measurements were paralleled by low serum protein levels.

VITAMIN D METABOLITES AND NUTRITION Undernourished patients with Crohn's disease had significantly reduced plasma $25-(\mathrm{OH}) \mathrm{D} 3$ compared with the other three groups $(\mathrm{p}<0.001)$ (Fig. 1). Plasma $24,25-(\mathrm{OH})_{2} \mathrm{D} 3$ was also very low in the undernourished Crohn's group, although both well nourished groups with inflammatory bowel disease had levels significantly below healthy controls $(\mathrm{p}<0 \cdot 05) \quad$ (Table 3). Plasma $1,25-(\mathrm{OH})_{2} \mathrm{D} 3$ was similar in all four groups. For all subjects studied there was a strong positive correlation between $25-(\mathrm{OH}) \mathrm{D} 3$ and $24,25-(\mathrm{OH})_{2} \mathrm{D} 3 \quad(\mathrm{r}=0 \cdot 828$, $\mathrm{p}<0.001, \mathrm{n}=67)$, although there was no correlation between $25-(\mathrm{OH}) \mathrm{D} 3$ and $1,25-(\mathrm{OH})_{2} \mathrm{D} 3(\mathrm{r}=0 \cdot 146)$. The undernourished Crohn's group produced more 1,25-dihydroxy cholecalciferol and less 24,25dihydroxy cholecalciferol in relation to the precursor 25- $(\mathrm{OH}) \mathrm{D} 3$ compared with normal controls $(p<0 \cdot 05)$, while the well nourished patients with inflammatory bowel disease had an intermediate

Table 2 Nutritional parameters in patients with Crohn's disease, ulcerative colitis and normal subjects

\begin{tabular}{lllc}
\hline & $\begin{array}{l}\text { Crohn's } \\
\text { MAC<90\% ideal }\end{array}$ & $\begin{array}{l}\text { Crohn's } \\
\text { MAC>90\% ideal }\end{array}$ & Ulcerative colitis \\
\hline Weight (\% ideal) & $85 \cdot 7 \pm 6 \cdot 7 \dagger$ & $110 \cdot 7 \pm 16 \cdot 0$ & $117 \cdot 9 \pm 17 \cdot 4$ \\
Midarm muscle circumference & $80 \cdot 8 \pm 6 \cdot 1^{\dagger}$ & $100 \cdot 5 \pm 11 \cdot 0$ & $100 \cdot 0 \pm 9 \cdot 9$ \\
(\% ideal) & $31 \cdot 5 \pm 10^{+}$ & $56 \cdot 4 \pm 27 \cdot 2$ & $61 \cdot 5 \pm 24 \cdot 1$ \\
Total skinfold thickness (mm) & $37 \cdot 6 \pm 6 \cdot 1^{*}$ & $42 \cdot 8 \pm 3 \cdot 9$ & $43 \cdot 1 \pm 2 \cdot 8$ \\
Serum albumin g/l & $23 \cdot 0 \pm 8 \cdot 1^{*}$ & $30 \cdot 0 \pm 6 \cdot 7$ & $27 \cdot 2 \pm 5 \cdot 2$ \\
Serum prealbumin mg/dl & & & $46 \cdot 4 \pm 25 \cdot 7$ \\
\hline
\end{tabular}

Results expressed as mean \pm 1 SD.

${ }^{*} \mathrm{p}<0 \cdot 01$.

$+\mathrm{p}<0 \cdot 001=$ significance values compared with well nourished Crohn's group. 


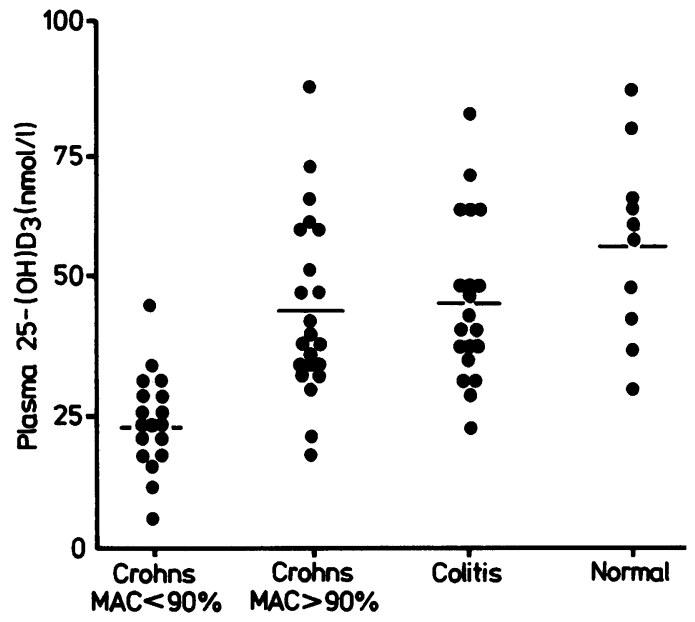

Fig. 1 Plasma 25-(OH)D3 in patients with Crohn's disease, ulcerative colitis and normal subjects during the summer. Patients with Crohn's disease are in two groups: undernourished with midarm circumference (MAC) less than $90 \%$ ideal standard; well nourished with midarm circumference (MAC) greater than $90 \%$ ideal standard. Mean levels are indicated.

position (Table 3).

VITAMIN D METABOLITE CONCENTRATIONS AND CLINICAL PARAMETERS IN CROHN'S DISEASE Concentrations of plasma 25- $(\mathrm{OH}) \mathrm{D} 3$ (mean \pm 1 SD) were significantly lower in patients with active disease $(25 \cdot 3 \pm 1 \cdot 0 \mathrm{nmol} / 1, \mathrm{n}=11)$ compared with patients who had inactive disease $(39.3 \pm 18.3 \mathrm{nmol} /$ $1, n=29)-p<0 \cdot 05$. There was also a significant inverse correlation between serum orosomucoid concentrations and 25-(OH)D3 (Fig. 2). Otherwise, 25-(OH)D3 and the two dihydroxylated metabolites were not affected by clinical parameters, and results were not significantly different between patients on and off steroids.

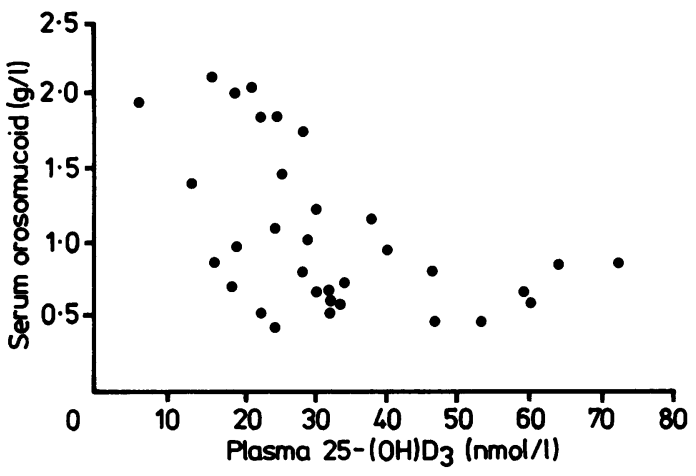

Fig. 2 Serum orosomucoid and plasma 25-OH)D3 in patients with Crohn's disease during the summer. Correlation coefficient $r=-0.487, p<0.01, n=33$.

DIETARY VITAMIN D INTAKE

In those patients who completed the diary, total daily vitamin $\mathrm{D}$ intake (mean \pm one $\mathrm{SD}$ ) was $3 \cdot 7 \pm 2 \cdot 9$ $\mu \mathrm{g}$ in 12 undernourished Crohn's patients; $4 \cdot 6 \pm 2 \cdot 3$ $\mu \mathrm{g}$ in 16 well nourished patients; $5 \cdot 1 \pm 3.8 \mu \mathrm{g}$ in 15 with ulcerative colitis and $4.4 \pm 1.9 \mu \mathrm{g}$ in six normal subjects. None of these differences were significant. In patients with Crohn's disease there was no significant correlation between daily vitamin D intake and 25-(OH)D3 concentrations (Kendall's $\tau=0 \cdot 172$ ).

\section{BIOCHEMICAL PARAMETERS IN RELATIONSHIP TO} 25 $(\mathrm{OH}) \mathrm{D} 3$

Corrected calcium and serum phosphate were both normal and similar between the four groups. Undernourished Crohn's patients, however, had significantly increased total alkaline phosphatase activity compared with the other three groups $(p<0.01)$ (Fig. 3). Well nourished Crohn's patients and ulcerative colitis patients, however, also had mean levels higher than normal subjects $(\mathrm{p}<0.05)$. Eleven

Table 3 1,25-(OH $)_{2} \mathrm{D} 3$ and 24,25-(OH $)_{2}$ D3 concentrations in patients with Crohn's disease, ulcerative colitis and normal subjects

\begin{tabular}{|c|c|c|c|c|}
\hline & $\begin{array}{l}\text { Crohn's } \\
M A C<90 \% \text { ideal }\end{array}$ & $\begin{array}{l}\text { Crohn's } \\
\text { MAC }>90 \% \text { ideal }\end{array}$ & Ulcerative colitis & Normal subjects \\
\hline Plasma 1,25-(OH $)_{2} \mathrm{D} 3 \mathrm{pmol} / \mathrm{l}$ & $124 \cdot 1 \pm 67 \cdot 2$ & $107 \cdot 0 \pm 32 \cdot 2$ & $109 \cdot 2 \pm 52 \cdot 6$ & $126 \cdot 5 \pm 36 \cdot 7$ \\
\hline Plasma $24,25-(\mathrm{OH})_{2} \mathrm{D} 3 \mathrm{nmol} / 1$ & $0.60 \pm 0.46 \dagger$ & $1.56 \pm 1.06$ & $1.63 \pm 1.03$ & $2 \cdot 88 \pm 1 \cdot 42$ \\
\hline$\frac{\text { Ratio } 1,25-(\mathrm{OH})_{2} \mathrm{D} 3 \mathrm{nmol} / \mathrm{l}}{25-(\mathrm{OH}) \mathrm{D} 3 \mathrm{nmol} / \mathrm{l}} \times 100 \%$ & $0.59 \pm 0.39^{*}$ & $0 \cdot 28 \pm 0 \cdot 11$ & $0 \cdot 28 \pm 0 \cdot 18$ & $0.25 \pm 0.09$ \\
\hline$\frac{\text { Ratio } 24,25-(\mathrm{OH})_{2} \mathrm{D} 3 \mathrm{nmol} / \mathrm{l}}{25-(\mathrm{OH}) \mathrm{D} 3 \mathrm{nmol} / \mathrm{l}} \times 100 \%$ & $2 \cdot 6 \pm 1 \cdot 81$ & $3 \cdot 4 \pm 1 \cdot 43$ & $3.4 \pm 1 \cdot 75$ & $5 \cdot 0 \pm 1 \cdot 46$ \\
\hline
\end{tabular}

The ratios of each dihydroxylated metabolite to its precursor, 25-(OH)D3, are also shown. Results are expressed as Mean \pm 1 SD.

${ }^{*} \mathrm{p}<0.01$. $+\mathrm{p}<0.001=$ significance values compared with well nourished Crohn's group. 


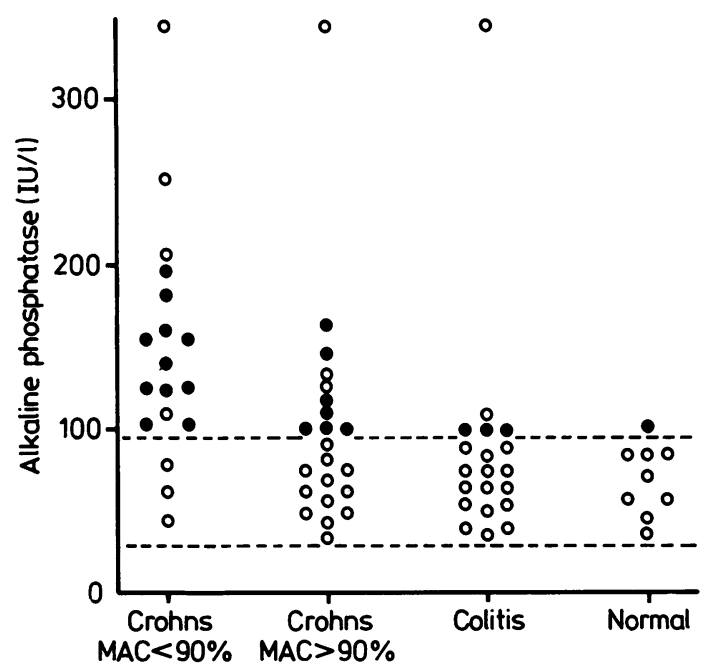

Fig. 3 Total alkaline phosphatase concentrations in patients with Crohn's disease, ulcerative colitis, and normal subjects during the summer. Black dots represent patients with raised alkaline phosphatase concentrations associated with raised bone isoenzyme and/or normal gamma glutamyl transferase. Horizontal dotted lines represent the normal range (30-95 IU/l).

of 15 undernourished Crohn's patients with raised total alkaline phosphatase had an increased bone isoenzyme $(n=7)$ and/or a normal gamma glutamyl transferase $(n=9)$. All subjects had normal aspartate transaminase concentrations.

Plasma parathormone was raised above $1.0 \mathrm{ng} / \mathrm{ml}$ in 10 undernourished Crohn's patients $(55.6 \%)$, eight well nourished Crohn's patients $(36.4 \%)$, five with ulcerative colitis $(25 \%)$ and no healthy subjects. In all 40 patients with Crohn's disease there was a significant inverse correlation between parathormone and 25- $(\mathrm{OH}) \mathrm{D} 3(\mathrm{r}=-0.356, \mathrm{n}=40$, $\mathrm{p}<0.05$ ). Hand radiology was normal in all patients investigated with no signs suggesting hyperparathyroidism.

\section{Discussion}

This study shows that the majority of undernourished Crohn's patients had low levels of 25-(OH)D3 during the summer months. Many patients had raised parathormone concentrations which may have explained the normal concentrations of 1,25 $(\mathrm{OH})_{2} \mathrm{D} 3$. Although their corrected calcium and phosphate concentrations were normal, these patients had high levels of alkaline phosphatase and this appeared to be predominantly of bone origin. In striking contrast well nourished Crohn's patients, patients with ulcerative colitis, and normal healthy subjects had similar results: levels of $25-(\mathrm{OH}) \mathrm{D} 3$ and $1,25-(\mathrm{OH})_{2} \mathrm{D} 3$ were normal, and most patients had normal parathormone concentrations.

The greatest difference between the two Crohn's groups was that the undernourished patients had active disease. Disease activity was measured by a simple clinical index ${ }^{9}$ which has been found to correlate with the more comprehensive Crohn's disease activity index ${ }^{16}$ and by serum orosomucoids which also reflect disease activity. ${ }^{17}$ Active disease may be associated with a protein losing enteropathy ${ }^{18}$ which may account for the low levels of 25- $(\mathrm{OH}) \mathrm{D} 3$. Vitamin D metabolites circulate in plasma bound to an alpha-2-protein, and in other protein losing states such as the nephrotic syndrome, low $25-(\mathrm{OH}) \mathrm{D} 3$ is thought to be caused by excess loss of the protein bound metabolite in the urine. ${ }^{19}$ Other clinical parameters and steroid medication did not appear to be responsible for the low concentrations of $25-(\mathrm{OH}) \mathrm{D} 3$, and the dietary findings are in keeping with other observations that dietary vitamin D intake is not important for maintaining adequate vitamin D3 levels. ${ }^{20}{ }^{21}$ Similarly malabsorption of vitamin D3 due to steatorrhoea probably contributed little to the low levels of $25-(\mathrm{OH}) \mathrm{D} 3$ in the malnourished Crohn's patients. Patients with Crohn's disease had normal serum aspartate transaminase levels, and this would tend to rule out liver disease as a cause for low vitamin D concentrations.

It is possible that the undernourished Crohn's group had low 25-(OH)D3 because of ultra violet deprivation as a result of bowel symptoms; this is unlikely, however, because all patients were outpatients and claimed to indulge in normal outdoor activity. Sufficient vitamin D is probably generated in the summer in the undernourished patients, but low $25-(\mathrm{OH}) \mathrm{D} 3$ is most likely to be due to excess loss of the vitamin from the gastrointestinal tract as a result of protein losing enteropathy and an interrupted enterohepatic circulation. Communities which have a good overall exposure to ultra violet light may still have a high prevalence of osteomalacia and rickets. ${ }^{22-24}$ One explanation is that these communities feed chiefly on poor vegetarian and cereal based diets that may bind to bile acid vitamin D complexes and cause vitamin D wastage severe enough to lead to bone disease through an interrupted enterohepatic circulation. ${ }^{25}$ More direct evidence comes from a recent study ${ }^{26}$ where plasma disappearance of intravenously administered $3 \mathrm{H}$ (25-(OH)D3) was more rapid in patients with malabsorption, including a number with Crohn's disease, compared with controls; the authors felt that loss of endogenous vitamin D in these patients 
could be a result of an interrupted enterohepatic circulation.

No subject in the study had symptoms or signs of osteomalacia. Calcium and phosphate concentrations were always normal, but the majority of patients in the undernourished Crohn's group had raised alkaline phosphatase concentrations, largely from bone. In previous work ${ }^{27}$ high alkaline phosphatase levels were attributed to liver disease, but this study did not include details of isoenzymes to alkaline phosphatase nor measurements of 5-nucleotidase or gamma glutamyl transferase, so their conclusions about the prevalence of bone disease are open to discussion. More substantial evidence for osteomalacia would require bone biopsy, but this was not thought to be justified on a group of patients who were on the whole asymptomatic. Clearly, however, osteomalacia is now recognised to be more common than previously suspected in Crohn's disease and may exist without clinical or biochemical abnormalities. $^{28} 29$

We conclude that undernourished patients with Crohn's disease, who may be identified by simple measurements of the midarm circumference, have reduced vitamin $D$ levels compared with nourished patients and a control population, and that one of the principal determinants of this low vitamin D status is an increased disease activity. These patients should avoid drugs such as cholestyramine which may further lower $25-(\mathrm{OH}) \mathrm{D} 3,{ }^{30}$ and should take advantage of the sun whenever possible and in winter might benefit from vitamin $D$ supplements. Whether improvement in nutrition and disease activity would be associated with an improvement in vitamin D status would require further investigation.

\section{References}

1 De Luca HF. Vitamin D: revisited 1980. Clin Endocrinol Metabol 1980; 9: 3-26.

2 Malluche H, Henry H, Meyer-Sabellek W, Sherman D, Massry S, Norman AW. Effects and interactions of $24 \mathrm{R}, 25-(\mathrm{OH})_{2} \mathrm{D} 3$ and $1,25-(\mathrm{OH})_{2} \mathrm{D} 3$ on bone. $\mathrm{Am} \mathrm{J}$ Physiol 1980; 238: E494-8.

3 Tanaka Y, Wichmann JK, Schnoes H, De Luca HF. Isolation and identification of 23,25-Dihydroxyvitamin D3, an in vivo metabolite of vitamin D3. Biochemistry 1981; 20: 3875-9.

4 Reinhardt TA, Napoli JL, Praminick B, et al. 1,25,26Trihydroxyvitamin D3: an in vivo and in vitro metabolite of vitamin D3. Biochemistry 1981; 20: 6230-5.

5 Wichmann J, Schnoes H, De Luca HF. 23,24,25Trihydroxyvitamin D3, 24,25,26-Trihydroxyvitamin D3, 24,keto-25-hydroxyvitamin D3 and 23-dehydro-25- hydroxyvitamin D3: New in vivo metabolites of vitamin D3. Biochemistry 1981; 20: 7385-91.

6 Driscoll R, Meredith S, Wagonfeld J, Rosenberg I. Bone histology and vitamin D status in Crohn's disease (CD): assessment of vitamin D therapy. Gastroenterology 1977; 72: 1051.

7 Compston J, Creamer B. Plasma levels and intestinal absorption of 25-hydroxyvitamin $\mathrm{D}$ in patients with small bowel resection. Gut 1977; 18: 171-5.

8 Sonnenberg A, Ehms H, Sonnenberg G, Strohmeyer G. 25-hydroxycholecalciferol serum levels in patients with Crohn's disease. Acta Hepatogastroenterol (Stuttg) 1977; 24: 293-5.

9 Harvey R, Bradshaw J. A simple index of Crohn's disease activity. Lancet 1980; 1: 514 .

10 Jelliffe DB. The assessment of the nutritional status of the Community. WHO Monograph Series no. 53, Geneva: WHO, 1966.

11 Society of Actuaries. Build and blood pressure study. Vols. 1 and 2. Chicago: Society of Actuaries, 1959.

12 Zilva PF, Pannall PR. Clinical chemistry in diagnosis and treatment. London: Lloyd-Luke, 1971: 198.

13 Woodhead JS, Simpson J, Davies S, Foster H, Davies C. Accuracy and precision in automated immunoassay systems. In: Wilson D, Gaskell S, Griffiths K, eds. Quality control in clinical endocrinology. Cardiff: Alpha-Omega, 1981: 117-25.

14 O'Riordan J, Clemens T, Hendy G, Fraher L, Sandler L, Papapoulos S. Radio immunoassay for circulating 1,25- and 25,26-dihydroxycholecalciferol in man. In: Vitamin D: basic research and its clinical application. Berlin, New York: Walter de Gruyter 1979: 221-7.

15 Clemens T, Hendy G, Papapoulos S, Fraher L, Care A, O'Riordan JL. Measurement of 1,25-dihydroxycholecalciferol in man by radio immunoassay. Clin Endocrinol 1979; 11: 225-34.

16 Best W, Becktel J, Singleton J, Kern F. Development of a Crohn's disease activity index. National cooperative Crohn's disease study. Gastroenterology 1976; 70: 439-44.

17 Andre C, Descos L, Landais P, Fermanian J. Assessment of appropriate laboratory measurements to supplement the Crohn's disease activity index. Gut 1981; 22: $571-4$.

18 Beeken WL, Busch HJ, Sylwester DL. Intestinal protein loss in Crohn's disease. Gastroenterology 1972; 62: 207-15.

19 Goldstein D, Yoshitaka O, Kurokawa K, Massry S. Blood levels of 25-hydroxyvitamin D in nephrotic syndrome. Studies in 26 patients. Ann Intern Med 1977; 87: 664-7.

20 Preece M, Tomlinson S, Ribot C, et al. Studies of vitamin D deficiency in man. $Q J$ Med (New Series) 1975; 44: 575-89.

21 Poskitt E, Cole T, Lawson D. Diet, sunlight and 25-hydroxyvitamin $\mathrm{D}$ in healthy children and adults. $\mathrm{Br}$ Med J 1979; 1: 221-3.

22 Hess AF. Rickets, osteomalacia and tetany. London: Henry Kimpton, 1930.

23 Wilson DC. The incidence of osteomalacia and late rickets in Northern India. Lancet 1931; 2: 10-12.

24 Reinhold JG. High phytate content of rural Iranian 
bread: a possible cause of human zinc deficiency. Am J Clin Nutr 1971; 24: 1204-6.

25 Dunnigan M, McIntosh W, Ford J, Robertson I. Acquired disorders of vitamin $\mathrm{D}$ metabolism. In: Heath D, Marx S, eds. Clinical endocrinology 2: Calcium disorders. London: Butterworth Scientific, 1982.

26 Batchelor AJ, Watson G, Compston JE. Changes in plasma half-life and clearance of $3 \mathrm{H}-25$-hydroxyvitamin D3 in patients with intestinal malabsorption. Gut 1982; 23: $1068-71$.

27 Dyer NH, Dawson AM. The incidence and significance of liver dysfunction in Crohn's disease. Digestion 1972; 5: $317-25$.

28 Compston J, Horton L, Ayers A, Tighe J, Creamer B. Osteomalacia after small intestinal resection. Lancet 1978; 1: 9-12.

29 Driscoll RH, Meredith SC, Sitrin M, Rosenberg IH. Vitamin $\mathrm{D}$ deficiency and bone disease in patients with Crohn's disease. Gastroenterology 1982; 83: 1252-8.

30 Compston J, Horton L. Oral 25-hydroxyvitamin D3 in treatment of osteomalacia associated with ileal resection and cholestyramine therapy. Gastroenterology 1978; 74: 900-2. 